\title{
A cyclic factorial typology of Pama-Nyungan stress*
}

\author{
Juliet Stanton \\ Massachusetts Institute of Technology
}

\section{Introduction}

In many languages, the phonology of morphologically complex words is influenced by their morphological composition. This influence can be manifested as accentual faithfulness: the stress of a complex word can resemble the stress of its base or another related word. For illustration, consider the schematic example in (1), similar to patterns observed in Seri (Martlett 2009) and others.

(1) Accentual faithfulness

Monomorphemic words
a. óo
b. oóo
c. òoóo
d. óo-o (*ó-o)
e. oóo-o (*òoó-o $)$
f. òoóo-o (*oòoó-o)

Monosyllabic suffixes

Penultimate stress in monomorphemic forms is invariant (1a-c). In suffixed forms (1d-f), by contrast, stress falls on the antepenultimate syllable. These deviations from penultimate stress serve a function: by retaining stress on the antepenult, stress of the suffixed stems matches stress of the stems in isolation.

In this paper I show that an analysis of accentual faithfulness using base-derivative (BD) correspondence constraints (Benua 1997) makes accurately restrictive predictions for the typology of accentual faithfulness. The paper focuses on 23 Pama-Nyungan (PN) and neighboring Australian Aboriginal languages, e.g. Dyirbal (Dixon 1972, Berry 1998), Diyari (Austin 1981, Poser 1989), and Warlpiri (Nash 1980, Berry 1998) ${ }^{1}$. In monomorphemic forms, the languages' stress patterns are identical. In suffixed forms, their stress patterns diverge.

Following the analysis, I discuss the results of a factorial typology. The preliminary version of the typology overgenerates, predicting all attested systems as well as a number of unattested ones. Many of the unattested systems share a common core: constraints whose activity is evident in frequent forms are dominated by constraints that lack such evidence. I introduce a mechanism that precludes the possibility of these interactions. This results in accurately restrictive typological predictions.

The final results of the typology are compared to Alderete's (2009) study, which explores predictions of alignment-based approaches to PN stress (e.g. Crowhurst 1994, Kager 1997). Both factorial typologies predict the full range of attested patterns, but differ in the nature of the unattested systems they predict.

\section{Analysis}

In Pintupi, Dyirbal, Diyari, and Warlpiri, monomorphemic words are stressed identically. Primary stress falls on the initial syllable, and all odd non-final syllables receive secondary stress (2).
Monomorphemic stress in Warlpiri
a. ó wáti 'man'
$\begin{array}{lll}\text { a. óo } & \text { wáti } & \text { 'man' } \\ \text { b. óoo wátiya } & \text { 'tree' }\end{array}$
c. óoòo mánangkàrra
d. óoòoo wíjipitirli
'spinifex plain'
'hospital'
(Nash 1980: 102)
(Nash 1980: 102)
(Nash 1980: 102)
(Berry 1998: 37)

\footnotetext{
* I am grateful to Donca Steriade, Adam Albright, Edward Flemming, Michael Kenstowicz, Sam Zukoff, and audiences at M@90, Phonology 2013, and MIT Phonology Circle for helpful feedback.

${ }^{1}$ See the appendix, available at http://web.mit.edu/juliets/www/ph2013appendix.pdf, for a list of languages.
}

\section{(C) 2014 Juliet Stanton}

Proceedings of Phonology 2013

Completed December 19, 2013 
The pattern in (2) can be captured simply with four foot-free accentual phonotactic constraints (see Kager 2001, Gordon 2002). In all forms, stress falls on the initial syllable (STRESSL). Stress clashes are avoided (*Clash), as is final stress (NONFinALITY). Lapses, if present, are limited to the last two syllables of the word (LAPSE@END). A tableau for the stress pattern of wijipitirli follows (3).

(3)

Stress in monomorphemic forms
\begin{tabular}{|l||c:c|c|c|}
\hline \multicolumn{1}{|c|}{ ooooo } & STRESSL & $*$ CLASH & NONFIN & L@E \\
\hline \hline > a. óoòoo & & & & \\
\hline b. oóoòo & $* !$ & & & \\
\hline c. óoòòo & & $* !$ & & \\
\hline d. óoòoò & & & $* !$ & \\
\hline e. óooòo & & & & $* !$ \\
\hline
\end{tabular}

In suffixed forms, the four languages' stress patterns diverge. The Pintupi pattern (4) is familiar: regardless of morphological composition, all forms exhibit the alternating pattern in (2).

Pintupi suffixal stress (Hansen \& Hansen 1969)
$\begin{array}{lll}\text { a. óoòo } & \text { málawàna } & \text { 'through (from) behind' } \\ \text { b. óoòoo } & \text { púlinkàlatju } & \text { 'we (sat) on the hill' } \\ \text { c. óoòoòo } & \text { tjámulìmpatjùnku } & \text { 'our relation' }\end{array}$

In the remaining three languages, the addition of suffixes can result in unexpected violations of LAPSE@END. One form each from Diyari (5a), Warlpiri (5b), and Dyirbal (5c) illustrate.
Unexpected violations of LAPSE@END

$\begin{array}{llll}\text { a. óoo-o } & \text { púlyuda-nhi } & \text { 'mud-LOC' } & \text { (Austin 1981) } \\ \text { b. óo-o-òo } & \text { yáparla-ngúrlu } & \text { 'FaMo-Elative' } & \text { (Nash 1980: 101) } \\ \text { c. óoo-ò-oo } & \text { mándalay-mbàl-mbila } & \text { 'play-COM-LEST' } & \text { (Berry 1998: 40) }\end{array}$

I trace these violations of LAPSE@END to the activity of morphologically conditioned constraints (see Kenstowicz 1998, Steriade 2013a for similar analyses). The diverging patterns of stress in complex forms are attributed to different types of base-derivative relations, and different rankings of a constraint regulating base-derivative identity.

2.1 BD correspondence In most theories of lexical faithfulness (e.g. Benua 1997, Bermúdez-Otero 2011), possible base-derivative correspondent pairs are limited to morphologically complex words and the exponents of their immediate syntactic subconstituents (their 'local' bases). Evidence from PN stress demonstrates the need to relax this restriction (see also Steriade 2008, Steriade \& Yanovich to appear). In some languages (e.g. Warlpiri, Diyari), complex forms correspond with their local bases; in others (e.g. Dyirbal), complex forms correspond with subconstituents of their local bases ('remote' bases) ${ }^{2}$.

To formalize the language-specific choice among bases, I introduce two base preference constraints (see Steriade \& Yanovich to appear): $\operatorname{CORRB}_{\mathrm{L}}$ (6) and $\mathrm{CORRB}_{\mathrm{R}}(7)$ Subscripts 'L' and 'R' are meant to evoke 'local' and 'remote', respectively.

(6) CORRB $_{\mathrm{L}}$ : morphologically complex forms correspond with their local bases.

$\mathrm{CORRB}_{\mathrm{R}}$ : stems of morphologically complex forms correspond with their stems in isolation.

In languages where complex forms preferentially correspond with their local bases, CORRB $\mathrm{B}_{\mathrm{L}}>>$ CORRB $_{R}$. In languages where stems of complex forms preferentially correspond with their stems in isolation, CORRB $\mathrm{C}_{\mathrm{R}}>>\mathrm{CORRB}_{\mathrm{L}}$. BD identity is regulated via BD-(ID)STRESS (8).

$$
\text { BD-STRESS: one * for each [ } \alpha \text { stress] syllable in a derivative that is }[-\alpha \text { stress] in its base. }
$$

\footnotetext{
${ }^{2}$ Faithfulness to a remote base is attested in Chamorro; see Crosswhite (1998: 312-14) for the relevant evidence.
} 
I assume that all complex forms correspond with one and only one base. This restriction has the effect of eliminating candidates that correspond simultaneously with multiple bases, or with none. Accentual faithfulness effects are present when BD-STRESS $>$ some MARKEDNESS, and absent when all MARKEDNESS $>$ BD-STRESS.

2.2 Preference for local bases: $\operatorname{CORRB}_{L}$ In Warlpiri, stress of morphologically complex forms matches the stress of their local bases. Representative data are in (9).

Stress in Warlpiri (a-b from Nash 1980:
$\begin{array}{lll}\text { a. óoo } & \text { 'átiya } & \text { 'tree'-e from Berry 1998: 23) } \\ \text { b. óoò-o } & \text { wátiyà-rla } & \text { 'tree-LOC' } \\ \text { c. óoo-òo } & \text { yáparla-ngùrlu } & \text { 'FaMo-ELATIVE' } \\ \text { d. óo-òo-o } & \text { yápa-rlàngu-rlu } & \text { 'person-e.g.-ERGATIVE' } \\ \text { e. óo-o-òo } & \text { wángka-ja-jàna } & \text { 'speak-PST-3pl/NS' }\end{array}$

wángka-ja-jàna $(9 \mathrm{e})$ shows that violations of LAPSE@END are permitted when necessary to satisfy BD-STRESS ([óo-o $]_{\mathrm{L}-\text { òo }}>*$ [óo-ò $\left.]_{\mathrm{L}}-\mathrm{oo}\right)$. (9e) also shows that CORRB $\mathrm{L}_{\mathrm{L}}$ dominates LAPSE@END and CoRRB . $_{\mathrm{R}}$. Correspondence with the local base is prioritized over avoiding LAPSE@END violations through correspondence with the bare stem $\left([\text { óo-o }]_{\mathrm{L}}\right.$-òo $>*[\text { óo }]_{\mathrm{R}}$-ò-oo) $(10)$.

\begin{tabular}{|c|c|c|c|c|}
\hline $\begin{array}{c}\text { oo-o-oo } \\
\mathrm{B}_{\mathrm{L}}:\left[\text { óo-o], } \mathrm{B}_{\mathrm{R}}:[\text { óo }]\right.\end{array}$ & $\mathrm{CORRB}_{\mathrm{L}}$ & BD-STRESS & L@E & $\mathrm{CORRB}_{\mathrm{R}}$ \\
\hline > >a. [óo-o] $]_{\mathrm{L}}-\mathrm{òo}^{3}$ & & & * & * \\
\hline b. [óo-ò] $]_{\mathrm{L}}-\mathrm{OO}$ & & $* !$ & & $*$ \\
\hline c. $[\mathrm{óo}]_{\mathrm{R}}-\mathrm{O}-\mathrm{OO}$ & $* !$ & & & \\
\hline
\end{tabular}

A comparison between wátiya (9a) and wátiyà-rla (9b) motivates *EXTLAPSE (no sequences of three stressless syllables), as distinct from LAPSE@END. In (9b), BD-STRESS is violated to satisfy *EXTLAPSE. NONFINALITY must also dominate BD-STRESS, to exclude *wátiya-rlà $(11 \mathrm{c})$.

\begin{tabular}{|c|c|c|c|}
\hline $\begin{array}{c}\text { ooo-o } \\
\mathrm{B}_{\mathrm{L}}:[\mathrm{óoo}] \\
\end{array}$ & NONFIN & *EXTLAPSE & BD-STRESS \\
\hline$>$ a. [óoò] $]_{\mathrm{L}}-\mathrm{O}$ & & & $*$ \\
\hline b. [óoo $]_{\mathrm{L}}-\mathrm{O}$ & & $* !$ & \\
\hline c. [óoo $]_{\mathrm{L}}$-ò & $* !$ & & \\
\hline
\end{tabular}

In Warlpiri ${ }^{4}$, an additional preference for affix-initial stresses outranks the preference for basederivative identity. Relevant data are in (12).
Affix-initial stress in Warlpiri
a. óoò-o
wátiyà-rla
'tree-LOC'
b. óoo-ò-o
wátiya-rlà-rlu
'tree-LOC-ERG'
(Nash 1980: 102)
c. óoo-ò-oo wátiya-rlà-juku 'tree-LOC-STILL'
(Nash 1980: 102)
(Alderete 2009: 20)

The current analysis predicts (12c), but not (12b): the latter violates both LAPSE@END and BD-STRESS. I interpret the pattern in (12b) as a result of a preference for edge-marking (see Crowhurst 1994, Kager 1997 for alignment-based statements). The constraint enforcing this preference is $\operatorname{STRESSL}(\mu)$ (see Steriade 2013b): affixes receive initial stress. In Warlpiri, $\operatorname{STRESSL}(\mu)>>$ BD-STRESS (13).

\footnotetext{
${ }^{3}$ Square brackets surround the part of the morphologically complex word that is in correspondence with the base. The subscript indicates whether the base is local or remote.

${ }^{4}$ Also in Wambaya; see Nordlinger (1993).
} 


Stress shift motivated by $\operatorname{STRESSL}(\mu)$
\begin{tabular}{|c||c|c|}
\hline $\begin{array}{c}\text { ooo-o-o } \\
\mathrm{B}_{\mathrm{L}}:[\text { òoó-o }]\end{array}$ & $\operatorname{STRESSL}(\mu)$ & BD-STRESS \\
\hline \hline >a. [òoo-ó $]_{\mathrm{L}}-\mathrm{o}$ & $*$ & $* *$ \\
\hline b. $[\text { òoó-o }]_{\mathrm{L}}-\mathrm{o}$ & $* * !$ & \\
\hline
\end{tabular}

STRESSL $(\mu)$ must also be dominated by *CLASH and NONFINALITY, as the preference for morpheme-initial stress cannot compel clashes ([óoò-o]-òo $>*$ [óoo-ò]-òo) or license final stress ([óoò]-o >*[óoo]-ò).

As in Warlpiri, Diyari complex forms correspond with their local bases (14). In all forms, monosyllabic suffixes are stressless (14a-b), and polysyllabic suffixes are stressed like stems (14b-c).
Diyari stress (a,c from Berry 1998: 38-39, b from Alderete 2009: 20; see Austin 1981, Poser 1989)
a. óo-o-o
b. óoo-o-òo
c. óoo-òo-òo
máda-la-nthu
púluru-ni-màta
'hill-CHARAC-PROP'
'mud-LOC-IDENT'
c. óoo-òo-òoo yákalka-yìrpa-màli-rna
'ask-BEN-RECIP-PART'

(14a) shows that BD-STRESS dominates both *EXTLAPSE and LAPSE@END ([óo-o $\left.]_{\mathrm{L}}-\mathrm{o}>*[\text { óo-ò }]_{\mathrm{L}}-\mathrm{o}\right)$. In addition, final stress is not permitted to satisfy BD-STRESS and *EXTLAPSE, so NONFINALITY $>>$

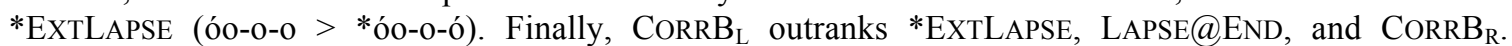
Establishing correspondence with the local base is more important than avoiding lapse violations through correspondence with the bare stem $\left([\text { óo-o }]_{\mathrm{L}}-\mathrm{O}>*[\text { óo }]_{\mathrm{R}}-\mathrm{ò}-\mathrm{o}\right)$. See (15) for a summary.

\begin{tabular}{|c|c|c|c|c|c|c|}
\hline $\begin{array}{c}\text { oo-o-o } \\
\mathrm{B}_{\mathrm{L}}:\left[\text { óo-o], } \mathrm{B}_{\mathrm{R}}:[\mathrm{o} 0]\right.\end{array}$ & $\operatorname{CORRB}_{\mathrm{L}}$ & BD-STRESS & NONFIN & *EXTLAPSE & L@E & $\mathrm{CORRB}_{\mathrm{R}}$ \\
\hline$>$ a. $[\text { óo-o }]_{\mathrm{L}}-\mathrm{O}$ & & & & $*$ & $*$ & $*$ \\
\hline b. [óo-ò $]_{\mathrm{L}}-\mathrm{O}$ & & $* !$ & & & & $*$ \\
\hline c. [óo-o $]_{\mathrm{L}}-\mathrm{ò}$ & & & $* !$ & & $*$ & $*$ \\
\hline d. [óo $]_{\mathrm{R}}-\mathrm{ò}-\mathrm{O}$ & $* !$ & & & & & \\
\hline
\end{tabular}

2.3 Preference for remote bases: $\operatorname{CORRB}_{R} \quad$ Stress in Dyirbal morphologically complex forms is representative of a second type of base-derivative relation: stems of complex forms correspond with their stress patterns in isolation $(16)^{5}$.

Stress in Dyirbal (Berry 1998: 40, see also Dixon 1972)
a. óoò-o
búrgurùm-bu
'jumping ant-ERG'
b. óoo-ò-oo
mándalay-mbàl-mbila
'play-COM-LEST'
c. óoo-ò-o-o
bánagay-mbà-rri-nu
'return-COM-REFL-P/P'
d. óo-ò-oo
dyángga-nà-mbila
'eat-PRON-WITH'

Consider the contrast between búrgurùm-bu (16a) and mándalay-mbàl-mbila (16b). As in Warlpiri, Dyirbal trisyllabic roots attract final stress when followed by a single monosyllabic suffix (16a). Unlike Warlpiri, however, root-final stress is not preserved when an additional disyllabic suffix is added (16b).

It is impossible to explain the Dyirbal pattern by appealing to local bases alone. The Dyirbal form in (16b), óoo-ò-oo, is unfaithful to the presumed stress pattern of its local base ([òoó]-o). (16b) also incurs a violation of LAPSE@END that *óò-o-òo, the candidate faithful to the local base, does not.

Reference to the bare stem in isolation allows us to explain the contrast between (16a) and (16b). Stress shifts off the stem in (16b) because the resulting pattern, [óoo-ò-oo], is faithful to the stress pattern of the stem in isolation ([óoo]). Together, (16a) and (16b) show that both CORRB $\mathrm{R}_{\mathrm{R}}$ and BD-STRESS dominate $\mathrm{CORRB}_{\mathrm{L}}$ and LAPSE@END ([óoo $]_{\mathrm{R}}$-ò-oo $>*$ [óoò-o $]_{\mathrm{L}}-\mathrm{o} o$ ). Faithfulness to $\mathrm{B}_{\mathrm{R}}$ is prioritized over avoiding LAPSE@END violations through correspondence with $\mathrm{B}_{\mathrm{L}}(17)$.

\footnotetext{
${ }^{5}$ Jingulu (Pensalfini 1997, p.c.) exhibits an identical pattern in morphologically complex forms.
} 
$\mathrm{CORRB}_{\mathrm{R}}>>\mathrm{L} @ \mathrm{E}, \mathrm{CORRB}_{\mathrm{L}} ; \mathrm{BD}-\mathrm{STRESS}>>$ LAPSE@END

\begin{tabular}{|l||c:c|c:c|}
\hline $\begin{array}{c}\text { ooo-o-oo } \\
\mathrm{B}_{\mathrm{R}}:\left[\text { óoo], } \mathrm{B}_{\mathrm{L}}:[\text { óoò-o] }\right.\end{array}$ & CORRB $_{\mathrm{R}}$ & $\mathrm{BD}-\mathrm{STRESS}$ & $\mathrm{L} @ \mathrm{E}$ & $\mathrm{CORRB}_{\mathrm{L}}$ \\
\hline \hline > a. $[\text { óoo }]_{\mathrm{R}}-\mathrm{ò-oo}$ & & & $*$ & $*$ \\
\hline b. $[\text { óoò-o }]_{\mathrm{L}}$-òo & $* !$ & & & \\
\hline c. $[\text { óoò }]_{\mathrm{R}}-\mathrm{o}-\mathrm{òo}$ & & $* !$ & & $*$ \\
\hline
\end{tabular}

búrgurùm-bu (16a) motivates an additional ranking argument: *EXTLAPSE $>>$ BD-STRESS (18).

*EXTLAPSE $>$ BD-STRESS
\begin{tabular}{|c||c|c|}
\hline $\begin{array}{c}\text { ooo-o } \\
\mathrm{B}_{\mathrm{R}}:[\text { óoo] }\end{array}$ & $*$ EXTLAPSE & BD-STRESS \\
\hline \hline > a. [óoò $]_{\mathrm{R}-\mathrm{O}}$ & & $*$ \\
\hline b. $[\text { óoo }]_{\mathrm{R}}-\mathrm{O}$ & $* !$ & \\
\hline
\end{tabular}

\section{Factorial typology: preliminary results}

In a factorial typology, typological predictions of an analysis are explored by permuting rankings within a constraint set. Different sets of rankings define possible grammars. Many of these correspond to distinct surface patterns. BD faithfulness introduces a transderivational dependency: the phonology of complex forms is evaluated with reference to the output of a distinct evaluation. The current approach to lexical faithfulness adopts from Benua (1997) the hypothesis that constraint rankings are identical throughout a given grammar ${ }^{6}$. We assume then that the grammar of morphologically complex forms is identical to its grammar for simple forms. What this means is that a factorial typology incorporating BD correspondence must be explored in stages, each stage building on the output of some previous stage and remaining consistent with at least one possible set of crucial rankings that could have generated it.

The first stage of evaluation explores the factorial typology of unsuffixed forms ${ }^{7}$. The inputs were forms of two through five syllables. All non-harmonically bound candidates were considered ${ }^{8}$. All possible rankings of the constraint set generate the monomorphemic pattern for the languages discussed in §2 (19).

$$
\begin{array}{ll}
\text { Stage } & 1 \text { output } \\
\text { óo } & \text { óoóo } \\
\text { óoo } & \text { óoóoo }
\end{array}
$$

The inputs to Stage 2 are the disyllabic and trisyllabic outputs from Cycle 1, with added suffixes (20).

$$
\begin{aligned}
& \text { Stage } 2 \text { input } \\
& \begin{array}{lll}
{[\text { óo }]-0} & {[\text { óo]-oo }} & {[\text { óo]-ooo }} \\
{[\text { óoo }]-0} & {[\text { ooo }]-00} & {[\text { óoo]-ooo }}
\end{array}
\end{aligned}
$$

Because the base of the forms in (20) is both the local base and the stem in isolation, each surface stress pattern corresponds to two candidates. One corresponds with $\mathrm{B}_{\mathrm{L}}$, the other with $\mathrm{B}_{\mathrm{R}}$. All non-harmonically bound candidates were considered, with a small class of exceptions: among sets of candidates differing only in the location of a clash, only one was considered. This limitation of the candidate set was imposed due to difficulties in obtaining an adequately restrictive factorial typology for clash distribution in quantity insensitive languages (see Kager 2001, van Urk 2013), an issue beyond the scope of this paper. The possibility of Stage 2 patterns with stress clashes will be further discussed in $\S 4$.

Stage 2 generates ten surface patterns (21). Six of these, including all attested patterns (bolded), are presented below. See the appendix for the remaining four.

\footnotetext{
${ }^{6}$ Cf. Kiparsky 2000, Inkelas \& Zoll 2007 for alternative assumptions on this point.

${ }^{7}$ All factorial typologies were explored using OTSoft (Hayes et al. 2013).

${ }^{8}$ I do not account for the placement of primary stress.
} 
Examples of Stage 2 outputs

\begin{tabular}{|c|c|c|c|c|c|c|c|}
\hline $\begin{array}{l}\text { [óo]-ó } \\
{[\text { óo]-óo }} \\
{[\text { óo]-óoo }}\end{array}$ & $\begin{array}{l}\text { [óoó]-ó } \\
\text { [óoó]-óo } \\
\text { [óoó]-óoo }\end{array}$ & b. & $\begin{array}{l}{[\text { óo]-o }} \\
{[\text { óo]-óo }} \\
\text { [óo]-óoo }\end{array}$ & $\begin{array}{l}\text { [óoo]-ó } \\
\text { [óoo]-óo } \\
\text { [óoo]-óoo }\end{array}$ & c. & $\begin{array}{l}{[\text { óo]-ó }} \\
\text { [óo]-óo } \\
\text { [óo]-óoo }\end{array}$ & $\begin{array}{l}\text { [oóo]-ó } \\
\text { [oóo]-óo } \\
\text { [oóo]-óoo }\end{array}$ \\
\hline $\begin{array}{l}\text { [óo]-o } \\
\text { [óo]-óo } \\
\text { [óo]-óoo }\end{array}$ & $\begin{array}{l}\text { [óoó]-o } \\
\text { [óoo]-óo } \\
\text { [óoo]-óoo }\end{array}$ & e. & $\begin{array}{l}\text { [óo]-o } \\
\text { [óo]-óo } \\
\text { [óo]-óoo }\end{array}$ & $\begin{array}{l}\text { [óoó]-o } \\
\text { [óoó]-oo } \\
\text { [óoó]-oóo }\end{array}$ & f. & $\begin{array}{l}\text { [óo]-o } \\
\text { [óo]-óo } \\
{[\text { [óo]-óoo }}\end{array}$ & $\begin{array}{l}\text { [óoo]-0 } \\
\text { [óoo]-óo } \\
\text { [óoo]-óoo }\end{array}$ \\
\hline
\end{tabular}

(21d) is Martuthunira (Dench 1995), Warlpiri (Nash 1980, Berry 1998), Wambaya (Nordlinger 1993), Gooniyandi (McGregor 1990), Dyirbal (Dixon 1972, Berry 1998), and Jingulu (Pensalfini 1997, p.c.). (21e) is Pintupi (Hansen \& Hansen 1969), and (21f) is Diyari (Austin 1981). Fifteen other languages consistent with one of the bolded patterns are listed in the appendix.

Note that in all languages surveyed here (23 total), NONFINALITY and *CLASH are inviolable in both roots and complex forms. The consistent behavior of *CLASH and NONFINALITY is suggestive of a condition on the ranking of certain markedness constraints. This condition, visibility, is defined below.

\section{Visibility}

While (21d-f) are robustly attested, the other patterns are not. Each unattested pattern exemplifies one or more of the interactions among markedness constraints listed in (22).

$$
\begin{aligned}
& \text { Unattested rankings } \\
& \begin{array}{ll}
\text { a. } & \text { STRESSL }(\mu)>>\text { NONFINALITY } \\
\text { b. } & \text { STRESSL }(\mu)>>\text { * CLASH } \\
\text { c. } & \text { *ExLAPSE }>>\text { NONFINALITY } \\
\text { d. } & \text { STRESSL }(\mu)>>\text { STRESSL }
\end{array}
\end{aligned}
$$

The unattested rankings in (22) are united by a common thread: a constraint for which there is less positive evidence of activity ( $\operatorname{STRESSL}(\mu)$, EXTLAPSE) dominates a constraint for which there is an abundance (STRESSL, *Clash, NONFINALITY).

I refer to the richness of evidence for the activity of a given constraint as that constraint's visibility. A constraint's visibility is directly tied to the frequency of forms providing evidence for the constraint's activity. I equate the frequency of a sequence type in a corpus with the probability that learners will be exposed to that sequence type. A learner receives evidence for the activity of some constraint $\mathrm{C} 1$ every time she is presented with a token in which $\mathrm{C} 1$ conflicts with another active ${ }^{9}$ (i.e. winner-preferring) constraint, C2, and C1 is satisfied at the expense of C2 (23).

Evidence that a constraint is visible

A token provides evidence that $\mathrm{C} 1$ is visible if it shows that $\mathrm{C} 1>>\mathrm{C} 2$, and $\mathrm{C} 2$ is active.

Consider the following example. Although *LAPSE (no sequences of two consecutive stressless syllables) was not invoked in the analyses in $\S 2$, it is active in PN: all monomorphemic four-syllable tokens, in all languages studied, show that *LAPSE dominates ONESTRESS (only one stress per word). Thus *LAPSE is active (i.e. winner-preferring in some environment). Then tokens showing that some other constraint, $\mathrm{C} 1$, causes *LAPSE violations in some context provide evidence for the activity of $\mathrm{C} 1$. The number of tokens in which $\mathrm{C} 1>$ * LAPSE contribute to the overall evidence that $\mathrm{C} 1$ is active. The total number of tokens in which $\mathrm{C} 1$ causes violations of some other active constraint is $\mathrm{C} 1$ 's visibility index: we can compare constraints on this basis, including undominated ones.

\footnotetext{
${ }^{9}$ It is important that $\mathrm{C} 2$ be active because visibility is meant to differentiate two varieties of undominated constraint (a point I return to later): those that we call undominated because they are prioritized over other active constraints, and those that appear undominated because they do not conflict with other active constraints. The former class of undominated constraints is backed by positive evidence; the latter class is not.
} 
Visibility definition

A constraint, $\mathrm{C} 1$, has a visibility index of $n$ if $n$ tokens provide evidence for C1's activity.

In the domain of stress, certain constraints (like STRESSL) are backed by evidence from both short and long words (e.g. STRESSL $>>$ *LAPSE in óoo and óoóoo). Other constraints (like STRESSL $(\mu)$ ) are backed by evidence only in longer words (e.g. STRESSL $(\mu)>>$ BD-STRESS in Warlpiri and Wambaya óoo-ó-o). To compare the relative visibility of the constraints used in the analyses of PN languages, we need to know the frequency distribution of words by syllable count: this is a proxy for the likelihood a learner would encounter them. As a stand-in for learning corpuses, I use token frequencies available from 10 text collections $^{10}$. All texts are from languages surveyed for this study. The data are represented visually in Figure 1; see the appendix for raw token counts and percentages.

\section{Figure 1}
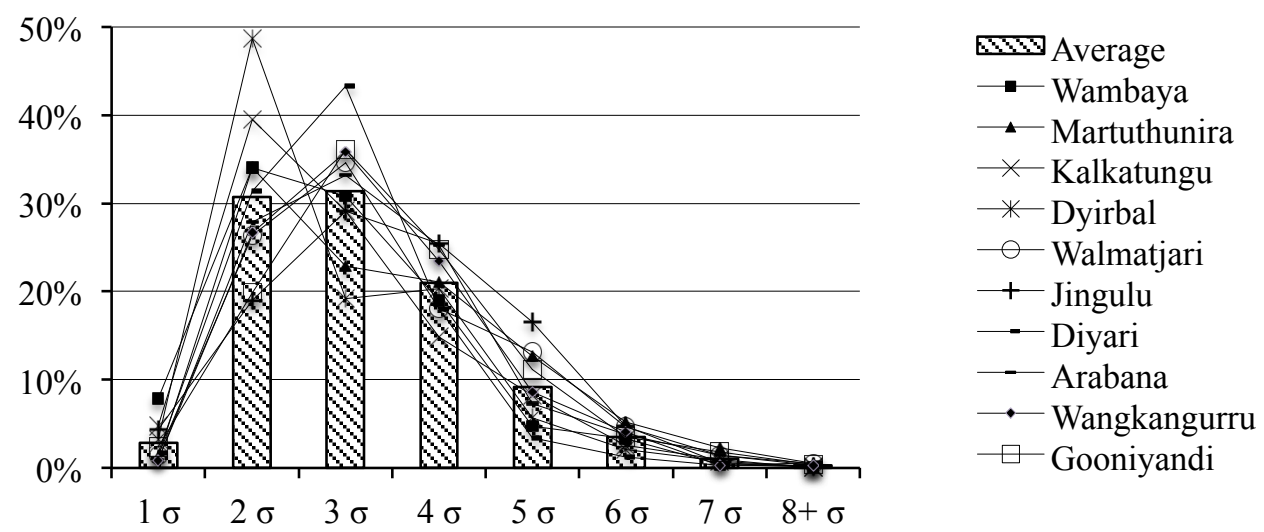

In all languages, token frequency peaks around 2-4 syllables and drops off from there. Words of four syllables or fewer are far more frequent than words of five syllables or more ( $86 \%$ vs. $14 \%$, on average).

Taking token frequencies from texts as a substitute for a learning corpus, it is very likely that children exposed to one of the languages in Figure 1 will construct grammars based primarily on patterns found in shorter words. Under a theory of learning like the Gradual Learning Algorithm (Boersma 1998, Magri 2012), the frequency asymmetries documented above have implications for acquisition. Constraints whose activity is visible in shorter words will acquire higher weights than constraints whose activity is visible in longer words, because they are supported by more positive evidence. From this, it follows that constraints backed by evidence from short words will dominate those backed by evidence from only long words.

Consider now how visibility interacts with the frequency asymmetries documented above. We have established that *LAPSE is active, as it crucially dominates ONESTRESS (óoóo $>$ *óooo). All trisyllabic forms (among others) provide positive evidence for STRESSL, *CLASH, and NONFINALITY: in those forms, the three constraints just listed are in conflict with *LAPSE. Since trisyllabic forms are frequent, the visibility indices of STRESSL, *CLASH, and NONFinality will always be high. In Wambaya, for example, trisyllabic forms alone make up 31\% (464/1509) of the total corpus.

It becomes important, at this point, to distinguish between two varieties of undominated constraint. We call constraints like STRESSL undominated because, in some form, they take priority over all other active constraints (e.g. STRESSL >>*LAPSE, in trisyllabic forms). Constraints like LAPSE@END, which look undominated in languages like Pintupi, do not conflict with any other active constraints. In Pintupi, the difference between STRESSL and LAPSE@END is not one of ranking, but one of visibility: both constraints are undominated, but only STRESSL has a high visibility index. In the languages surveyed here, the visibility index of LAPSE@END is zero, because it does not conflict with any other active constraints.

Visibility indices of the other two markedness constraints (*EXTLAPSE, $\operatorname{STRESSL}(\mu))$ are only slightly higher than that of LAPSE@END. In Wambaya and Warlpiri, for example, *EXTLAPSE conflicts with active

\footnotetext{
${ }^{10}$ Languages and sources: Arabana (Hercus 1994), Diyari (Austin 1981), Dyirbal (Dixon 1972), Gooniyandi (McGregor 1990), Jingulu (Pensalfini 1997), Kalkatungu (Blake 1979), Martuthunira (Dench 1995), Walmatjari (Hudson 1978), Wambaya (Nordlinger 1993), Wangkangurru (Hercus 1994).
} 
BD-STRESS (óoò-o $>*$ óoo-o). The shortest possible words demonstrating that *EXTLAPSE $>>$ BD-STRESS are [óoò $]_{\mathrm{L}}-\mathrm{O}$, and [óoò $]_{\mathrm{L}}-\mathrm{O}$; tokens of those particular forms are only a subset $(20 \%$, or $56 / 285$ in Wambaya) of four-syllable words in the corpus. Other forms showing that *EXTLAPSE $>>$ BD-STRESS are longer, and therefore rare (20 total in Wambaya). Although *EXTLAPSE is undominated in Wambaya, its visibility index (76) is lower than the visibility indices of undominated STRESSL (464), *CLASH (481), and NonFInALITY (547). This is because it does not conflict with active constraints in frequent forms.

Similarly, in Warlpiri and Wambaya, the argument that $\operatorname{STRESSL}(\mu)>>\operatorname{BD}-\operatorname{STRESS}$ comes from only a small number of longer morphologically complex forms, (ex: [óoo-ò $]_{\mathrm{L}}-\mathrm{O}>$ *[óoò-o $]_{\mathrm{L}}-\mathrm{o}$ ). Although Wambaya forms of this type (e.g. gáguwi-ni-ni, 'fish-I-LOC') are provided by Nordlinger (1993: 34), none appear in the texts. Thus in this particular corpus, the visibility index of STRESSL $(\mu)$ is zero.

Comparing the visibility indices (VIs) for all markedness constraints in Wambaya yields the table in (25). While StRESSL, *Clash, and NonFinAlity are supported by an abundance of positive evidence, STRESSL $(\mu)$, *EXTLAPSE, and LAPSE@END are not. Although the exact VIs are specific to Wambaya, we expect the clear asymmetry in (25) to hold across all languages surveyed here.

Visibility indices in Wambaya
\begin{tabular}{|l|c|c||c|c|c|}
\hline Constraint & $V I$ & $\%$ & Constraint & $V I$ & $\%$ \\
\hline NONFIN & 547 & $36 \%$ & $*$ EXTLAPSE & 76 & $5 \%$ \\
\hline$*$ CLASH & 481 & $32 \%$ & STRESSL $(\mu)$ & 0 & $0 \%$ \\
\hline STRESSL & 464 & $31 \%$ & LAPSE@END & 0 & $0 \%$ \\
\hline
\end{tabular}

We can now posit a split between two classes of constraints (25). The constraints on the left side of the table (NONFINALITY, *CLASH, STRESSL) have high visibility indices because evidence for their activity comes from frequent forms. The constraints on the right side (*EXTLAPSE, STRESSL $(\mu), \operatorname{LAPSE} @$ END) have low visibility indices because evidence for their activity, if present, comes from infrequent forms. I refer to the former class as highly visible (26), since positive evidence for their activity comes from forms a learner would frequently encounter. I refer to the latter class as invisible (27), since positive evidence for their activity comes from forms a learner would infrequently (or never) encounter. At present, it is impossible to offer precise and generally valid criteria for assigning constraints to these classes.

Highly visible constraints

A constraint $\mathrm{C} 1$ is highly visible if its VI is high, e.g. it is visible in high-frequency forms

Invisible constraints

A constraint C2 is invisible if its VI is low, e.g. it is not visible in high frequency forms

Now recall the rankings in (22), summarized in (28), that generated the unattested Stage 2 patterns.
Unattested rankings
a. $\operatorname{STRESSL}(\mu)>>$ NONFINALITY
b. $\operatorname{STRESSL}(\mu)>>$ CLASH
c. *EXTLAPSE $>>$ NONFINALITY
d. $\operatorname{STRESSL}(\mu)>>$ STRESSL

In each case, an invisible constraint dominates a highly visible constraint. The hypothesis here is that this does not happen: invisible constraints do not dominate highly visible ones ${ }^{11}$ (29).

Visibility hypothesis (VH)

If a constraint $\mathrm{C} 1$ is highly visible and a constraint $\mathrm{C} 2$ is invisible, $\mathrm{C} 1>>\mathrm{C} 2$.

The VH predicts that STRESSL, *CLASH, and NONFINALITY (the highly visible constraints) must always dominate STRESSL $(\mu)$, LAPSE@END, and *EXTLAPSE (the invisible constraints). Each of the 23 languages surveyed here is consistent with this set of fixed rankings. Note that (29) predicts nothing about

\footnotetext{
${ }^{11}$ The VH resembles Hayes's (2004: 22) Favor Activeness principle: active faithfulness constraints (winner-preferrers)
} are ranked highly, but inactive constraints (neither winner- nor loser-preferrers) are not (see also Prince \& Tesar 2004). 
relationships among constraints that fall within the same visibility stratum. This allows for LAPSE@END >> $\operatorname{STRESSL}(\mu)$, as in Pintupi; it also allows for $\operatorname{STRESSL}(\mu)>$ LAPSE@END, as in Warlpiri and others.

The VH could ultimately be derived from a learning algorithm like the GLA that makes use of constraint promotion. The $\mathrm{VH}$ and the GLA, however, make some diverging predictions that merit investigation. Most importantly, there are OT-consistent rankings that are inconsistent with the VH. Specifically, if the visibility index of $\mathrm{C} 1$ is much smaller than that of $\mathrm{C} 2$, the $\mathrm{VH}$ predicts that learners will not converge on a grammar in which $\mathrm{C} 1>\mathrm{C} 2$, even if $\mathrm{C} 1 \gg \mathrm{C} 2$ is OT-consistent. The GLA does not predict that certain OT-consistent rankings should be learnable, to the exclusion of others.

Framed in these terms, the VH is a hypothesis about learnability, making crucial reference to properties of the input. It's not that the unattested rankings in (28) are impossible; it's that, given the frequency asymmetries inherent in the learning corpus, the rankings in (28) will not be learned.

\section{Factorial typology: final results}

We can now use the visibility hypothesis to determine a set of rankings that must hold in the languages surveyed here. Because StRESSL, ${ }^{*} \mathrm{ClASH}$, and NONFINALITY are highly visible, they must dominate invisible STRESSL $(\mu)$, *EXTLAPSE, and LAPSE@END (30).

Rankings derived from the visibility hypothesis StRESSL, NonFinality, *CLASh $>>$ STRESSL $(\mu)$, ${ }^{*}$ ExtLAPSE, LAPSE@END ${ }^{12}$

Integrating the set of fixed rankings in (30) into the typology leads to a significant decrease in the number of predicted Stage 2 patterns. While the preliminary typology predicted ten patterns, the final typology predicts only three. I refer to these as pattern A (31a), B (31b), and C (31c). All are attested.

\section{Stage 2 (Final)}
a. [óo]-o
[óo]-óo
[óo]-óoo
[óoó]-o
[óoo]-óo
b. [óo]-o
[óo]-óo
[óo]-óoo
[óoó]-o
[óoó]-oo
c. [óo]-o
[óo]-óo
[óo]-óoo
[óoo]-o
[óoo]-óo
[óoo]-óoo

Exploring Stage 3 involves multiple evaluations, as all Stage 2 outputs have distinct grammars and will give rise to a distinct set of Stage 3 outputs. A Stage 3 input, based on pattern C (31c) follows (32).

$$
\begin{aligned}
& \text { Stage } 3 \text { input for pattern } \mathrm{C}
\end{aligned}
$$

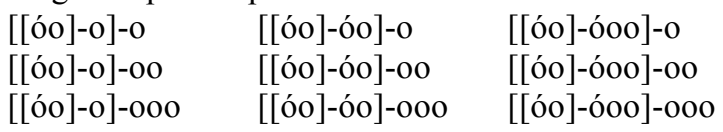

$$
\begin{aligned}
& \text { [[óoo]-o]-o [[óoo]-óo]-o [[óoo]-óoo]-o } \\
& \text { [[óoo]-o]-oo [[óoo]-óo]-oo [[óoo]-óoo]-oo } \\
& \text { [[óoo]-o]-ooo [[óoo]-óo]-ooo [[óoo]-óoo]-ooo }
\end{aligned}
$$

For Stage 3, most non-harmonically bound candidates were considered. (Candidates incompatible with grammars that could have generated the corresponding Stage 2 pattern were excluded.) Each surface stress pattern corresponds to two candidates: one in correspondence with $B_{L}$, one in correspondence with $B_{R}$.

Grammars for doubly suffixed forms must be consistent with grammars for singly suffixed forms, so it is necessary to consider all sets of rankings that could have generated (31c). The two possible sets of rankings are below (33).

$$
\begin{aligned}
& \text { Possible grammars for pattern C } \\
& \text { NONFINALITY }>>\text { STRESSL }(\mu), \text { *EXTLAPSE } \\
& \text { BD-STRESS }>>\text { LAPSE@END, }{ }^{*} \text { EXTLAPSE } \\
& \text { CORRB }_{L}>>\text { CORRB }_{R} \text { OR } \text { CORRB }_{R}>>\text { CORRB }_{L}
\end{aligned}
$$

\footnotetext{
12 * LAPSE is not included in this set of fixed rankings because it was not included in the analysis or factorial typology.
} 
The Stage 3 typology for pattern $\mathrm{C}$ was explored twice, once for each possible grammar in (33). The analysis predicts five distinct surface patterns. An identical procedure was used in exploring the Stage 3 outputs for patterns A and B. Across Stage 3, the typology predicts twelve patterns (34). See the appendix for surface patterns, ranking arguments, and full analyses.

Predicted and attested systems

\begin{tabular}{|c|c|c|c|c|c|}
\hline \multicolumn{2}{|c|}{ Type } & Language & \multicolumn{2}{|c|}{ Type } & Language \\
\hline \multirow{6}{*}{ A } & 1 & Martuthunira (Dench 1995) & $\mathrm{B}$ & 1 & Pintupi (Hansen \& Hansen 1969) \\
\hline & 2 & $\begin{array}{l}\text { Warlpiri (Nash 1980, Berry 1998) } \\
\text { Wambaya (Nordlinger 1993) }\end{array}$ & \multirow{5}{*}{$\mathrm{C}$} & 1 & Diyari (Austin 1981) \\
\hline & 3 & Gooniyandi (McGregor 1990) & & 2 & (unattested) \\
\hline & 4 & Dyirbal (Dixon 1972, Berry 1998) & & 3 & (unattested) \\
\hline & 5 & Jingulu (Pensalfini 1997, p.c.) ${ }^{14}$ & & 4 & (unattested) \\
\hline & 6 & (unattested) & & 5 & (unattested) \\
\hline
\end{tabular}

At least six of these systems exist; as many as six are unattested. Unlike the Stage 2 patterns eliminated by the $\mathrm{VH}$, the unattested patterns in (34) are either minor variations on, or composites of, attested systems. $\mathrm{C} 2$ is similar to Warlpiri, but BD-STRESS is only violated to satisfy $\operatorname{STRESSL}(\mu)$. C3/C4 are similar to A4/A5: the only difference is that *EXTLAPSE >> BD-STRESS in A4/A5, while the reverse holds in C3/C4.

In $\mathrm{A} 6$ and $\mathrm{C} 5$, correspondence is preferentially established with the local base $\left(\mathrm{CORRB}_{\mathrm{L}}>\mathrm{CORRB}_{\mathrm{R}}\right)$, but complex forms correspond with their remote bases if faithfulness to $B_{R}$ better satisfies certain markedness constraints. In A6, correspondence with $B_{R}$ is established only to better satisfy LAPSE@END. In C5, complex forms are faithful to $\mathrm{B}_{\mathrm{L}}$ unless total identity leads to a violation of *EXTLAPSE, in which case they correspond with $B_{R}$. Neither system is attested, but see Steriade \& Yanovich (to appear) for discussion of an architecturally similar base preference effect in Ukrainian nominal derivatives.

None of the unattested patterns depart too radically from what is known about the typology of stress in complex words. Unlike the Stage 2 systems eliminated by the VH, there is no thread that unites them. The basic difference between the unattested patterns in (34) and the patterns ruled out by the VH is that, here, markedness constraints backed by frequent positive evidence (i.e. STRESSL, *CLASH, NONFINALITY) are inviolable in monomorphemic and complex forms alike. There are no patterns in (34) where final stress is banned in monomorphemic forms, for example, but regularly allowed in complex forms.

\section{Comparison with Alderete (2009)}

Alderete (2009) presents sets of factorial typologies for alignment-based approaches to PN stress (see Crowhurst 1994, Kager 1997, Berry 1998, Pensalfini 1999). The most restrictive typology generating all attested languages $(-\mathrm{R},+\mathrm{S},+\mathrm{Gr})$ predicts 26 distinct patterns. For a comparison I discuss only the patterns with the monomorphemic stress pattern in $\S 2$ (16 in total), as this is the scope of the BD factorial typology.

Of these sixteen, several predicted systems are inconsistent with the VH. A representative example is in (35). Forms violating MAINLEFT (main stress foot must be aligned with the left word edge) are bolded.

$$
\begin{aligned}
& \text { Output \#23 (-R,+S,+Gr) } \\
& \text { óo-o óo-óo oóo-o óoo-óo } \\
& \text { óo-o-o óo-óo-o oóo-o-o óoo-óo-o } \\
& \text { óo-o-óo óo-óo-óo oóo-o-óo óoo-óo-óo }
\end{aligned}
$$

In the bolded forms, stress shifts to the second syllable due to two constraints: TAUTOMORPHFT (feet never straddle a morpheme boundary) and PARSESYLL2 (no two adjacent syllables are unfooted). TAUTOMORPHFT dominates PARSESYLL2, which dominates MAINLEFT, yielding the stress shift (36).

\footnotetext{
${ }^{13}$ Stress in Gooniyandi is variably quantity sensitive. Trisyllabic words are usually óoo but can be oóo if the second syllable has a long vowel; four-syllable words are usually óoóo but possibly oóoo if the second syllable has long vowel (McGregor 1990: 120-123). This does not influence stress in morphologically complex words.

${ }^{14}$ Patterns A4 and A5 are differentiated only by the stress patterns of words with trisyllabic suffixes. From the available data, it is impossible to determine whether Dyirbal or Jingulu exemplify A5 or A6.
} 


Stress shift in [oóo-o-óo]
\begin{tabular}{|l||c|c|c|}
\hline \multicolumn{1}{|c|}{ ooo-o-o } & TAUTOMORPHFT & PARSESYLL2 & MAINLEFT \\
\hline \hline > a. o(óo)-o-o & & $*$ & $*$ \\
\hline b. (óo)o-o-o & & $* * !$ & \\
\hline c. (óo)o-(ó-o) & $* !$ & & \\
\hline d. (óo)(ó-o)-o & $* !$ & & \\
\hline
\end{tabular}

The system in (35) is unattested. This is an effect of visibility. MAINLEFT requires that the main stress foot be aligned with the left edge of the word. This constraint, like STRESSL, is highly visible: it is in conflict with active *LAPSE in all three-syllable forms. PARSESYLL2, like *EXTLAPSE, penalizes sequences of three stressless syllables. Also like *EXTLAPSE, it is only visible in a subset of longer morphologically complex words. The ranking PARSESYLL2 > MAINLEFT, necessary for an analysis of (35), is one where an invisible constraint outranks a highly visible constraint. This is predicted by the VH to be impossible.

Fixing MAINLEFT > PARSESYLL2 reduces Alderete's typology to 12 PN-like systems, compared to the BD typology's equivalent $10^{15}$. In both typologies, all systems are consistent with the visibility hypothesis, and all attested patterns are predicted.

But this is largely where the similarities end: the additional predictions made by the two typologies are almost non-overlapping sets. While both the BD typology and Alderete's $(-\mathrm{R},+\mathrm{S},+\mathrm{Gr})$ typology predict system C2 (a system similar to Warlpiri), the BD typology is unique in predicting A6, C5, and C3/C4. Alderete's typology, in turn, predicts five systems that the BD typology does not. Each of these additional predicted systems is a ranking paradox for the BD constraint set. Two representative examples, annotated with ranking arguments, are below (37); see the appendix for the remaining three.

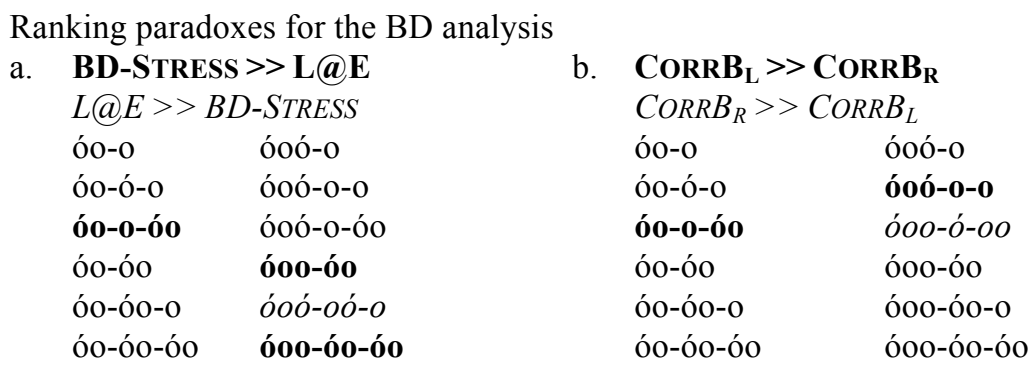

The ranking paradox in (37a) is between BD-STRESS and LAPSE@END. [óoo-óo] and [óo-o-óo] suggest LAPSE@END $>$ BD-STRESS, but [óoó-oó-o] suggests the opposite. In (37b), the paradox is between $\mathrm{CORRB}_{\mathrm{L}}$ and $\mathrm{CORRB}_{\mathrm{R}}$. [óoó-o-o] and [óo-o-óo] suggest that correspondence with local bases ([óoó-o] and [óo-o], respectively) is prioritized over correspondence with bare stems; [óoo-ó-oo], however, suggests the opposite. Unlike the violable base preference effect documented in Steriade \& Yanovich (to appear), the apparent selection among bases in $(37 \mathrm{~b})$ is not motivated by phonotactic considerations. [óo-o-óo], in correspondence with [óo-o $]_{\mathrm{L}}$, incurs a violation of LAPSE@END that the candidate faithful to $\mathrm{B}_{\mathrm{R}}$, *[óo-ó-oo] does not. [óoo-ó-oo], in correspondence with [óoo $]_{R}$, incurs a violation of LAPSE@END that the candidate faithful to $\mathrm{B}_{\mathrm{L}}$, *[óoó-o-óo], does not.

\section{Conclusion}

This paper presents an analysis of stress in PN languages that makes use of asymmetric BD correspondence, foot-free accentual phonotactics, and foot-free faithfulness. The constraint set employed in the analyses presented in $\$ 2$, when supplemented by the visibility hypothesis, makes accurately restrictive predictions for the typology of morphologically conditioned stress.

The predictions of the BD typology are slightly more restrictive than those of Alderete (2009). The more interesting comparison lies in the nature of the predicted but unattested systems. The BD typology predicts three systems that Alderete's does not. Alderete's typology, in turn, predicts five systems that the

\footnotetext{
${ }^{15}$ Alderete does not consider trisyllabic suffixes. Several pairs of systems (A4/A5, C3/C4) in the BD typology only differ in this domain, so eliminating these forms for a comparison brings the number of predicted systems down to 10.
} 
BD typology does not. Whether or not these diverging predictions speak to the success of one particular approach remains to be determined, as the typological space is not fully defined. Many of the unattested predictions made by the two constraint sets are non-overlapping, so further descriptive work would be necessary to arbitrate between their resulting factorial typologies.

\section{References}

Alderete, John (2009). Exploring recursivity, stringency, and gradience in the Pama-Nyungan stress continuum. Phonological argumentation: Essays on evidence and motivation, 181-202.

Austin, Peter K. (1981). A grammar of Diyari, South Australia. Cambridge: Cambridge University Press.

Benua, Laura (1997). Transderivational identity: phonological relations between words. Ph.D thesis: UMass Amherst.

Bermúdez Otero, Ricardo (2011). Cyclicity. In Marc van Oostendorp, Colin Ewen, Elizabeth Hume, \& Karen Rice (eds.), The Blackwell companion to phonology, vol. 4: 2019-2048. Malden, MA: Wiley-Blackwell.

Berry, Lynn (1998). Alignment and adjacency in Optimality Theory: Evidence from Warlpiri and Arrernte. Ph.D. thesis: University of Sydney.

Blake, Barry J. (1979). A Kalkatungu grammar (vol. 57). Canberra: Australian National University.

Boersma, Paul (1998). Functional Phonology. Ph.D. thesis, University of Amsterdam. The Hague: Holland Academic Graphics.

Crosswhite, Katherine (1998). Segmental vs. prosodic correspondence in Chamorro. Phonology 15. 281-316.

Crowhurst, Megan (1994). Prosodic alignment and misalignment in Diyari, Dyirbal, \& Gooniyandi: An optimizing approach. In Proceedings of the West Coast Conference on Formal Linguistics 13.

Dench, Alan Charles (1995). Martuthunira: A language of the Pilbara region of Western Australia (vol. 125). Canberra: Australian National University.

Dixon, R. M. (1972). The Dyirbal language of North Queensland. Cambridge: Cambridge University Press.

Gordon, Matthew (2002). A factorial typology of quantity insensitive stress. NLLT 20. 491-552

Hansen, K. C. \& L. E. Hansen (1969). Pintupi Phonology. Oceanic Linguistics 8. 153-170.

Hayes, Bruce (2004). Phonological Acquisition in Optimality Theory: The Early Stages. In René Kager, Joe Pater, \& Wim Zonneveld (eds.), Constraints in Phonological Acquisition, 158-203. Cambridge: Cambridge Univ. Press.

Hayes, Bruce, Bruce Tesar \& Kie Zuraw (2013). OTSoft 2.3.2, software package, http://www.linguistics.ucla.edu/people/hayes/otsoft/.

Hercus, Luise Anna (1994). A Grammar of the Arabana-Wangkangurru Language, Lake Eyre Basin, South Australia. Canberra: Australian National University.

Hudson, Joyce (1978). The core of Walmatjari grammar. Canberra: Australian Institute of Aboriginal Studies.

Inkelas, Sharon \& Cheryl Zoll (2007). Is grammar dependence real? A comparison between cophonological and indexed constraint approaches to morphologically conditioned phonology. Linguistics 45. 133-171.

Kager, René (1997). Generalized alignment and morphological parsing. Rivista di Linguistica 9. 245-282.

Kager, René (2001). Rhythmic directionality by positional licensing. Handout of a presentation at HILP5, University of Potsdam. ROA-514.

Kiparsky, Paul (2000). Opacity and cyclicity. The Linguistic Review 17. 351-365.

Kenstowicz, Michael (1998). Uniform Exponence: Exemplification and extension. Ms., MIT.

Magri, Giorgio (2012). Convergence of error-driven ranking algorithms. Phonology 29. 213-269.

Martlett, Stephen (2009). A grammar of Seri. Available online at htttp://www.und.nodak.edu/instruct/smarlett/Stephen_Marlett/GrammarDraft.html.

McGregor, William (1990). A functional grammar of Gooniyandi. Amsterdam: John Benjamins.

Nash, David (1980). Topics in Warlpiri grammar. Ph.D. thesis, MIT.

Nordlinger, Rachel (1993). A grammar of Wambaya. MA thesis: University of Melbourne.

Pensalfini, Robert (1997). Jingulu Grammar, Dictionary, and Texts. Ph.D. thesis, MIT.

Pensalfini, Robert (1999). Suffix coherence and stress in Australian languages. In John Henderson (ed.) Proceedings of the 1999 Conference of the Australian Linguistic Society.

Poser, William J. (1989). The metrical foot in Diyari. Phonology 6. 117-148.

Prince, Alan \& Bruce Tesar (2004). Learning phonotactic distributions. In René Kager, Joe Pater, \& Wim Zonneveld (eds.), Constraints in phonological acquisition, 245-291. Cambridge: Cambridge University Press.

Steriade, Donca (2008). A pseudo-cyclic effect in Romanian morphophonology. In Asaf Bachrach \& Andrew Nevins (eds.), Inflectional Identity, 313-359. Oxford: Oxford University Press.

Steriade, Donca (2013a). 24.964 lecture notes, MIT, Spring 2013.

Steriade, Donca (2013b). The Typology of Base-Derivative Similarity. Handout from Phonological Typology, University of Oxford.

Steriade, Donca \& Igor Yanovich (to appear). Accentual allomorphs in East Slavic: an argument for inflection dependence. In Eulàlia Bonet, Maria-Rosa Lloret and Joan Mascaró (eds.), Understanding Allomorphy. Sheffield, UK: Equinox Press.

van Urk, Coppe (2013). A typology of clash-tolerating langauges. Ms., MIT. 